\title{
Die Złedfffpredhumg
}

\section{Sex \\ Qbexfandesgexichte

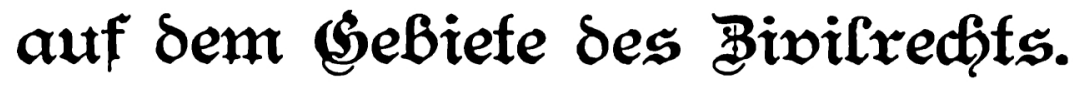

Sornuasgegeben bon

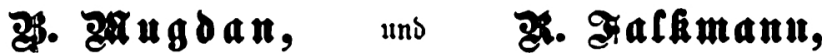 \\ fammergerimterat. \\ Senatsprafibent am sammergeridt.
}

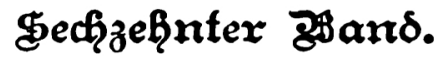

(すafjrgang 1908, erfítes \$albjafr.)

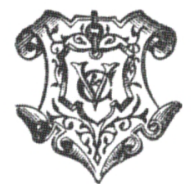

Seipzig,

Berlag von Beit \& Eomp. 